\title{
Kertomusmaailmojen kehystys ja kulttuuriperintö
}

The Framing of Story Worlds and Cultural Heritage

Les cadres des univers du récit et le patrimoine culturel

\section{Karina Lukin}

\section{OpenEdition}

\section{Journals}

Édition électronique

URL : https://journals.openedition.org/efo/4726

DOI : $10.4000 /$ efo. 4726

ISSN : 2275-1947

\section{Éditeur}

INALCO

\section{Édition imprimée}

Date de publication : 1 janvier 2014

ISBN : 978-2-343-05394-3

ISSN : 0071-2051

\section{Référence électronique}

Karina Lukin, «Kertomusmaailmojen kehystys ja kulttuuriperintö », Études finno-ougriennes [En ligne], 46 | 2014, mis en ligne le 05 novembre 2015, consulté le 08 juillet 2021. URL : http:// journals.openedition.org/efo/4726 ; DOI : https://doi.org/10.4000/efo.4726

Ce document a été généré automatiquement le 8 juillet 2021

\section{(c) (†) 8}

Études finno-ougriennes est mis à disposition selon les termes de la Licence Creative Commons Attribution - Pas d'Utilisation Commerciale 4.0 International. 


\title{
Kertomusmaailmojen kehystys ja kulttuuriperintö
}

\author{
The Framing of Story Worlds and Cultural Heritage \\ Les cadres des univers du récit et le patrimoine culturel
}

Karina Lukin

\section{NOTE DE L'AUTEUR}

Kenttätyöaineistot. Kirjoittajan hallussa.

MAC. Manuscripta Castreniana. Kansalliskirjasto.

1 “СЕВЕРУ НЕ ПОВЕЗЛО, Pohjoista ei onnistanut”, kirjoitti venäläinen etnografi ja lingvisti Nikolai Vahtin lakonisesti Venäjän pohjoisten kansojen kielten muutoksia käsittelevässä kirjassaan (Vahtin 2001: 250). Vahtin näkee pohjoiset kansat, niiden kielet ja perinteiset kulttuurit neuvostoaikaisen modernisaation häviäjinä, vaikkei allekirjoitakaan kaikkein pessimistisimpiä ja pelastusetnografisia näkemyksiä kielten ja perinteiden kuolemasta. Neuvostoaikoina suurin osa pohjoisen kieliyhteisöistä siirtyi kaksi- tai monikielisyydestä venäjänkielisiksi. Kuten monilla alueilla, myös nenetsien autonomisessa piirikunnassa kielenvaihto tapahtui huomaamattomasti, ja prosessista alettiin keskustella julkisesti vasta perestroikan aikaan tai vasta sen jälkeen (Menšakova (red.) 2003).

2 Päädyin itse 2000-luvun alussa asumaan ja elämään nenetsiyhteisössä, jossa tundranenetsi oli jokapäiväisen kommunikaation väline ainoastaan vähemmistölle. Olen tehnyt kenttätöitä Barentsin merellä sijaitsevan Kolgujevin saaren asukkaiden parissa neljän eri jakson aikana vuosina 2000-2005. Nämä jaksot ovat vaihdelleet pituudeltaan kahdesta viikosta kolmeen kuukauteen. Olen keskittynyt kenttätöiden aikana keräämään suullista perinnettä. Kesti jonkin aikaa ennen kuin ymmärsin, että suullista perinnettä esitetään myös venäjäksi, ja tämän havaittuani keskityin 
kolgujevilaisten venäjänkielisen puheen dokumentointiin. Niinpä aineistoni koostuu pääasiassa venäjäksi kerrotusta nenetsien folkloresta.

3 Pohdin tässä artikkelissa, miksi nenetsit kertovat folkloreaan venäjäksi, mitä he kertovat venäjäksi ja miten voimme tulkita näiden kertomusten merkityksiä. Kerron ensin, miten nenetsit ovat päätyneet tilanteeseen, jossa suullista perinnettä kerrotaan venäjäksi eikä sen alkuperäisellä kielellä, tundranenetsiksi. Käsittelen kertomusten merkityksiä kerrontatilanteen ja kertomusmaailman käsitteiden avulla ja analysoin niitä myös suhteessa kertomusten rakentamiin intertekstuaalisiin etäisyyksiin. Keskityn siihen, miten suullista perinnettä esitetään nenetsien autonomisessa piirikunnassa ja erityisesti siihen, miten piirikunnassa asuvat Kolgujevin nenetsit esittävät omaa perinnettään. Pohdin, miten nenetsiälymystön kerronta eroaa tavallisten kolgujevilaisten kerronnasta ja mistä nämä erot johtuvat. Valitsemani esimerkit koskevat šamanismia, minkä vuoksi artikkelissa käsitellään implisiittisesti myös nenetsien uskonnollisuuden muutosta. Analyysi keskittyy varsinaisesti kuitenkin kielen käyttöön yleisemmässä kielen muutokseen liittyvässä kontekstissa.

\section{Kolgujevin kielet historiassa}

4 Kuten Pertti Anttonen (2005: 27-39) on todennut, perinne ja sen kuolema on yksi modernin luomista kertomuksista. Vähän vastaavalla tavalla Jim Wilce (2009) on todennut, että modernistinen diskurssi tekee perinteen kuolemasta täysin luonnollisen ja vääjäämättömän tapahtuman. Wilce toruu tutkijoita ja korostaa, että tämän vääjäämättömyyden diskurssin taustalle jäävät usein ne väkivaltaiset historialliset tapahtumakulut, jotka ovat häviämisen taustalla ja joista usein kerrotaan suullisesti, ei kirjallisesti. Hahmotankin tässä luvussa lyhyesti niitä historiallisia, sosiaalisia ja kulttuurisia taustoja, jotka ovat johtaneet Kolgujevin nenetsien kielenvaihtoon. Tarkoituksenani ei ole luoda "itkuvirttä" perinteen kuolemasta, vaan pohtia kielenvaihdon syitä, jotta voisin käsitellä suullisen perinteen elämää kielenvaihdon jälkeen.

5 Nenetsien historiassa on tärkeää havaita, että yksin yhteydet venäläisten kanssa tai edes venäläisten lähtökohtaisesti dominoivampi asema ei tuottanut ennen vallankumousta tilannetta, jossa nenetsit olisivat ryhtyneet äidinkielensä sijasta puhumaan venäjää. Päinvastoin Kolgujevilla vierailleiden ulkopuolisten kuvausten perusteella piirtyy kuva kaksikielisyydestä. Erityisesti tämä on liittynyt pomorien ja nenetsien väliseen kaupankäyntiin ja poronhoitoon, mutta myös saarella vierailleiden pappien kanssa on kommunikoitu venäjäksi. Kolgujevin nenetsit ovat koko Kolgujevilla asumisensa aikana olleet suhteissa venäläisiin pomorikauppiaisiin tai -metsästäjiin: valtaosa on toiminut pomorien pororenkeinä. Suurin osa nenetseistä muutti saarelle vasta 1800-luvun puolivälissä ja sen jälkeen. Päätös muuttaa saarelle ja koko elämä saarella perustuu nenetsien ja venäläisten yhteisöjen läheiselle vuorovaikutukselle. (Ks. Lukin 2012: 26-33.)

6 Vallankumouksen jälkeen kauppaa ja muutakin vuorovaikutusta alettiin kontrolloida voimakkaammin, mikä heijastui ennen kaikkea talouden rakenteisiin kohdistuneisiin muutoksiin. Kolgujevin nenetsit ovat kokeneet monia sellaisia laajoja ja koko yhteisön elämään vaikuttavia muutoksia, joita muutkin Neuvostoliitossa ja Neuvostoliiton

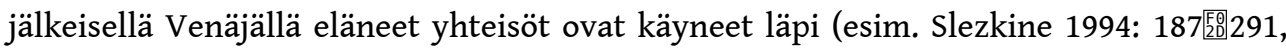
337區351). Vaikka talouden kollektivisaatio merkitsikin monia kiistämättömiä ja suuria 
muutoksia nenetsien ja venäläisten välisiin tai nenetsien sisäisiin omistajuussuhteisiin, vaikutuksiltaan syvemmät muutokset tapahtuivat vasta varsinaisen kollektivisaation jälkeen. Näiden, suurin piirtein 1950-luvulla alkaneiden muutosten tarkoituksena oli muuntaa kommunismi sosialismiksi, mikä käytännössä tarkoitti pohjoisessa toimia, jotka tähtäsivät yhteiskunnan modernisaatioon. Pieniä talousyksikköjä yhdistettiin suuremmiksi, hyvinvointiyhteiskunnan palveluja tuotiin ja tuotettiin pohjoiseen rakennettuihin asutuskeskuksiin. Samalla pohjoisessa aloitettiin luonnonvarojen hyödyntäminen, mikä tarkoitti, että aiemmin lähinnä hallinnossa ja kulttuurisektorilla työskennelleiden ulkopuolisten, prieezzhie, rinnalle tuli lisää uutta väestöä. Nämä ulkopuoliset, jotka edustivat venäläisten ja ukrainalaisten lisäksi koko Neuvostoliiton kansojen kirjoa, eivät olleet valmiita kohtaamaan nenetsien kulttuurin erilaisuutta. Monet tavat ja jopa nomadinen elintapa kokonaisuudessaan tulkittiin alempiarvoisesti tai muutoin negatiivisesti. (Grant 1995; Lyarskaya 2006; Sergejev 1955; Sokolova 1990; Tuisku 1999: 92-96, 161-162).

7 Internaatit mainitaan monissa sosialismin jälkeisissä pohjoista käsittelevissä etnografioissa yhtenä keskeisistä ympäristöistä, joissa negatiiviset asenteet alkuperäiskansojen kulttuuria kohtaan tulivat välitetyiksi. Internaattikoulujärjestelmää on syytetty alkuperäisväestön itsetunnon romahduttamisesta, perinteisen elämäntavan suosion laskemisesta nuoremman väestön keskuudessa ja pohjoisten kansojen äidinkielten hylkäämisestä. (Bloch 2004; Rokina 2003; Jermakov et al. 2003) Nenetsit itse pitävät myös vuoropaimennusjärjestelmää tärkeänä tekijänä, joka vaikutti itsetuntoon ja tundranenetsin puhumiseen. Vuoropaimennusjärjestelmä aloitettiin Kolgujevin saarella 1970-luvun lopulla. Tässä järjestelmässä ainoastaan paimenet työskentelevät tundralla vuoroissa, kun taas naiset ja lapset muuttavat kyliin. Näin eri sukupuolten edustajat elävät eri paikoissa, perheet hajoavat eikä poronhoidossa ja tundralla liikkumisessa vaadittavat käytännön taidot välity ongelmitta - tai laisinkaan. (Lukin 2012: 40医 41; Tuisku 2001)

8 Neuvostoaikoina tapahtuneita muutoksia voidaan luonnehtia modernisaation ja teollisen tuotannon tehostamisen yhdistelmäksi. Vahtinin mukaan neuvostoaikaiset laajat yhteiskunnalliset muutokset pohjoisiin kansoihin kohdistuneen rasismin ohella ovat merkittävimpiä tekijöitä kielenvaihdon takana. Vaikka kielenvaihto ei tapahtunut yhtäkkiä, vaan useiden vuosikymmenten kuluessa ja on meneillään edelleen, on sen alku sijoitettu useissa tutkimuksissa juuri 1950-luvun lopulle tai niihin sukupolviin, jotka aloittivat koulunkäyntinsä 1960-luvulla. Tällä hetkellä tundranenetsin asema nenetsien autonomisessa piirikunnassa on heikko. Luotettavaa tai muiden alueiden kanssa vertailukelpoista tilastotietoa ei ole tällä hetkellä saatavissa, mutta kokonaisuutta kuvaa esimerkiksi se, että vuoden 2002 väestölaskun mukaan 32\% Nenetsian nenetseistä ilmoitti pitävänsä tundranenetsiä äidinkielenään (Itogi 2004: 165). Yksittäiset kielisosiologiset kyselyt ovat myös osoittaneet, että kun 40[5050vuotiaista vielä suurin osa taitaa äidinkielensä, 20 -vuotiaat taas pääosin eivät sitä taida. Lisäksi joidenkin nenetsien suhtautuminen äidinkieltänsä kohtaan on kielteinen. (Rokina 2003; Jermakov et al. 2003.)

9 Tämän artikkelin kannalta olennaista on huomioida, että pohjoisten kielten aseman huonontuminen vaikutti myös niin, että näiden kielten poeettisen käytön tai funktioiden mahdollisuudet heikkenivät. Käytännössä tämä on tarkoittanut pahimmillaan sitä, että kieli on jäänyt ainoastaan osaksi tervehdyksiä, 
kulttuuritapahtumia ja virallisten tai julkisten tilanteiden rituaalisia aloituksia ja lopetuksia. Esimerkiksi nenetsien autonomisen piirikunnan alueella lähinnä vanhemmat nenetsit osaavat esittää folklorea tundranenetsiksi. Vastaavasti sekä tundranenetsin kieli että folklore ovat kulttuurieliitin harrastus tai osa heidän työtään, ja se elää lähinnä esiintymislavoilla. Kokonaisuudessaankin perinteinen tieto on muuntunut jokapäiväisestä osaamisesta ja toiminnasta "viisaiden kultaisiksi sanoiksi" kuten muidenkin pohjoisten kansojen parissa (Humphrey 1983: 230-231).

Siltikin folklorea esitetään nykyään tundranenetsiksi, perinnettä arvostetaan ja tämän esittäjiä ihaillaan paljon. Erityisesti nenetsit arvostavat edelleen eeppisiä genrejä, syudbabtseja ja yarabtseja. Ne ovat viime aikoina nousseet myös uudestaan esille laulukilpailuissa, joita Nar'yan-Marissa järjestetään (ks. esim. Divnye 2013), mutta kokonaisuudessaan näiden laulujen esittäjiä ei ole Uralin länsipuolisilla alueilla enää juurikaan elossa. Nenetsien henkilölaulut (syo, yabye"mya syo) ovat niin ikään hyvin suosittu genre, minkä lisäksi perinteistä proosaperinnettä (esimerkiksi lahanako) taitavia henkilöitä arvostetaan yhteisöissä edelleen. Šamanismin sinänsä sanotaan sammuneen Uralin länsipuolisilla tundrilla, mutta šamanistista rituaalilaulantaa esitetään edelleen virallisissa ja julkisissa tilanteissa erityisinä taiteellisina performansseina. Kokonaisuudessaan šamanismi ja siihen liittyvä tematiikka on yksi suosituimmista aiheista nenetsien suullisessa kerronnassa nykyään. Havaintoani tukevat nenetsien autonomisen piirikunnan suurimmassa lehdessä Nyaryana Vynderissa viime aikoina julkaistut šamanismiin viittaavat aineistot (esim. Hanzerova 2013; Sjudbya 2013). Nykyään suosittu kerronta koostuu tarinoista ja kertomuksista, joiden luonne on arkisempi. Niiden tutkimus on ollut hyvin hataraa, minkä lisäksi proosagenrejen nimitykset vaihtelevat alueittain hyvin paljon (esim. Kupriyanova 1965: 20).

Olen itse kerännyt kenttätöideni aikana nimenomaan tällaista proosakerrontaa, minkä vuoksi minulta puuttuu suoranainen geneerinen nenetsinkielinen vertailuaineisto, jolle voisin tutkimukseni perustaa. Aineistoni perusteella voi kuitenkin hahmottaa nenetsiyhteisön, joka esittää aktiivisesti historiallista ja paikallista kerrontaa sekä henkilökohtaista kerrontaa - venäjän kielellä. Niiden rakenteellinen tutkimus edellyttäisi juuri tuota puuttuvaa tundranenetsinkielistä aineistoa tai vielä laajempaa Kolgujevilta kerättyä kertomusperinnekorpusta. Olen rakenteellisen analyysin sijasta keskittynyt tutkimuksessani intertekstuaalisten yhteyksien ja suhteiden tutkimiseen. Tämänkaltainenkin analyysi on tuottanut mielenkiintoisia tuloksia, jotka koskevat suullisen perinteen siirtymistä kielenvaihdon kontekstissa.

Neuvostoliiton jälkeisessä yhteiskunnallisessa kontekstissa on pidettävä mielessä, että nenetsien puheen sisältöjä ja muotoja ei ole mielekästä sijoittaa ainoastaan nenetsien perinteen jatkumolle. Nenetsit ovat jo pitkään kommunikoineet paikallistasoa laajemmassa yhteiskunnallisessa kontekstissa, joka on monikulttuurinen, mutta leimallisesti monokielinen tai yksi- eli venäjänkielisyyteen rohkaiseva. Nenetsien parissa kulttuurisen julkisen esittämisen tavat ovat muodostuneet neuvostoaikoina vuorovaikutuksessa neuvostoliittolaisten ideologisten kehysten kanssa. Neuvostoliiton hajoamisen jälkeen esittämisen kanavat ovat moninkertaistuneet, minkä lisäksi joidenkin aiemmin kiellettyjen aiheiden - kuten šamanismin - esittäminen on tullut mahdolliseksi. Monet esittämisen tavat ja sisällöt ovat silti säilyttäneet asemansa. (ks. myös Siikala \& Ulyashev 2012) 


\section{Intertekstuaalisia etäisyyksiä}

13 Vaikka venäjänkielinen kerronta on nykyään tavanomaista Euroopanpuoleisten nenetsien keskuudessa, venäjä ei ole täysin syrjäyttänyt nenetsiä kommunikaation kielenä. Kielten välillä on jännite, mutta eri nenetsiryhmät ovat neuvotelleet suhteensa tähän jännitteeseen eri tavoin: monet nenetsiä taitavat välttävät kielen puhumista julkisilla paikoilla, mutta etenkin Nar'yan-Marin älymystön piirissä nenetsin kielen taitoa jopa arvostetaan. Kolgujevin saarelaiset käyttävät nenetsiä vielä perheiden sisällä kommunikoimiseen, mutta venäjää käytetään julkisilla paikoilla, esimerkiksi hallinnossa asioitaessa, postissa tai kaupassa, vaikka tarvittaessa myös nenetsin kielellä saisi palvelua. Vastoin yleisiä oletuksia, myös tundralla suurimman osan aikaansa viettävät paimenet puhuvat nenetsin sijasta venäjää. Koska nenetsit muistelevat ja kertovat kertomuksia usein laajoissa ryhmissä, perheen tai suvun kokoontumisissa tai juhlissa, näiden kieli tahtoo olla venäjä.

Kertoessaan kertomuksia tai muistellessaan vanhoja aikoja puhujat tahi kirjoittajat voivat monin erilaisin kommunikaation keinoin ilmaista, että he ovat esittämässä perinnettä. Toisin sanoen performanssin aikana kertojat ilmaisevat vaihtelevin, mutta kulttuurisesti ymmärrettävin keinoin esittävänsä perinnettä, mikä taas vaikuttaa yleisön tekemiin tulkintoihin. Puhe tai kirjoitus voidaan kehystää perinteeksi esimerkiksi käyttämällä kuvaannollista kieltä, paralingvistisiä keinoja, formuloita tai muita kulttuurisidonnaisia tapoja. (Bauman 1977: 17㡠22.) Richard Bauman ja Charles Briggs ovat esittäneet myös, että kertoja voi pienentää tai laajentaa esityksensä ja perinteen välistä eroa vastaavalla tavalla moninaisin keinoin. Baumanin ja Briggsin mukaan esittäjät ja kuulijat osallistuvat yhdessä esitettyjen tekstien intertekstuaalisten yhteyksien rakentamiseen niin, että esitykset tulevat osaksi suurempia merkityskenttiä ja sosiaalisten suhteiden verkostoja. (Bauman \& Briggs 1992: 149[20163)

Olen yhdistänyt näitä performanssikoulukunnan ajatuksia Katherine Youngin kerrontatilannetta (Storyrealm) ja kertomusmaailmaa (Taleworld) koskevaan analyysimalliin. Young argumentoi Goffmanin kehysanalyysin puitteissa, mutta hänen ajatuksensa on helposti yhdistettävissä lingvistisen antropologian laajempiin kehyksiin. En ole tekemässä kehysanalyysiä, vaan hyödyntämässä Youngin teorian käsitteitä ja ajatuksia. Kerrontatilanteella Young tarkoittaa kertomisen tapahtumaa eli sitä hetkeä, joka tulee rajatuksi laajemmasta keskustelukontekstin kehyksestä, kun kerronta alkaa. Kerrontatilanne koostuu tapahtumaan osallistuvista henkilöistä ja heidän suullisista akteistaan. Tämä tapahtuma johdattaa ja kuljettaa osallistujansa kohti kertomusmaailmaa eli kohti tapahtumaa, josta kerrotaan. Kertojan auktoriteetti perustuu hänen kykyynsä johdattaa kuuntelijat keskustelutilanteesta kerrontatilanteeseen ja kertomusmaailmaan, mutta myös sieltä pois kohti yleisempää kommunikaatiokehystä. Näin ollen hyvä kertoja kykenee liikkumaan eri maailmojen ja kontekstien välillä, jotta sekä kerrontatilanne että tapahtuma josta kerrotaan olisivat mielekkäitä ja merkityksellisiä laajemmassa keskustelukontekstissa. (Young 1987, erit. 22 㞔60.)

16 Young korostaa keskustelutilanteen, kerrontatilanteen ja kertomusmaailman erilaisia metafyysisiä oletuksia, jotka voidaan käsittää myös kertomisen, kuuntelemisen ja tulkinnan sääntöinä. Kertomusmaailmalla on Youngin mukaan omat tilan ja ajan lähtökohdat, jotka tämän maailman puitteissa ovat yhtä todellisia kuin sen hahmot ja niiden väliset suhteetkin. Kerrontatilanteessa kertoja tuo kertomusmaailmasta esille 
vain yhden osan, mutta kuuntelijat voivat kuvitella tai tuntea aiempien kuuntelukertojen tai muiden kokemustensa perusteella kertomusmaailmaa. (Young 1987: 16, 189.) Toisin sanottuna sekä kerrontatilanne että kertoja rajaavat kertomusmaailman ja esittävät siitä kerrontatilanteessa ainoastaan siinä hetkessä olennaisia, mielenkiintoisia ja merkityksellisiä osia. Intertekstuaaliset suhteet rakentuvat kerrontatilanteissa suhteessa kertojan ja kuulijan aikaisempiin tietoihin ja kokemuksiin aiheesta.

17 Tämän lisäksi erilaiset kertomusmaailmat ovat vuorovaikutuksessa toistensa kanssa, niiden piirteet liikkuvat maailmasta toiseen. Perinteen kertomusmaailmat voivat lainata piirteitä modernin kertomusmaailmoista tai kansanuskon kertomusmaailmoihin voidaan sekoittaa arkipäivän piirteitä. Näin kertojat voivat pienentää tai laajentaa myös kertomusmaailman piirteiden avulla kerrontansa intertekstuaalista yhteyttä perinteeseen. Vastaavalla tavalla kertojat voivat rakentaa yhteyksiä ja kosketuspintoja tundranenetsinkielisen ja venäjän kielellä kerrotun perinteen välille. Kertojat rakentavat yhteyksiä myös nenetsien suullisen perinteen yleisempiin todellisuuden jäsentämisen tapoihin, minkä lisäksi venäjänkielisessä kerronnassa liikutaan myös eri genrejen välillä. Erilaisten kehystysten avulla kertojat rakentavat suhteita keskustelukontekstin, kerrontatilanteen ja kertomusmaailman välille. Käytännössä nämä kehystykset ovat metakommentteja, jotka kommentoivat joko kertomusmaailman tai kerrontatilanteen tapahtumia, tapahtumien arvoa jne.

\section{Purpej ja kultainen mato}

Vaikka analyysimallin juuret ovat suullisen ilmaisun tutkimisessa, voidaan sitä soveltaa myös kirjallisten aineistojen tutkimukseen. Tällöin lähtökohtana voidaan pitää puheen etnografian laajempaa päämäärää selvittää kielen käytön symbolisia ja sosiaalisia ulottuvuuksia. Nar'yan-Marin älymystö julkaisee lehteä Vyngy vada (slovo tundry). Lehti on venäjänkielinen, vaikka se esittelee nenetsejä ja muutoinkin lähes kaikki lehdessä olevat artikkelit käsittelevät tavalla tai toisella asioita, jotka liittyvät nenetseihin. Edellä mainituista syistä tundranenetsi ei voisikaan olla lehden julkaisukieli, sillä ainoastaan vähemmistö lehden kohdeyleisöstä ymmärtäisi sitä. Lehdessä on osio, jonka otsikko on Legendy i mifi shamana Purpeja, Purpej-šamaanin tarinoita ja myyttejä. Osion on kirjoittanut Kolgujevin saarelta kotoisin olevan Filipp Ardeev, joka on tällä hetkellä Nar'yan-Marissa asuva, eläkkeellä oleva opettaja. Piirikunnan julkisuudessa Ardeev on usein esiintyvä persoona, joka antaa kasvot nenetsien kulttuurille, käsitöille, suulliselle perinteelle ja šamanismille. Lehden osiossa Ardeev esittelee kirjoittamiaan kertomuksia Kolgujevin historian huomattavimmasta šamaanista.

Ardeev on itse nauhoittanut isänsä tundranenetsinkielisiä kertomuksia ja suunnittelee niiden julkaisemisesta. Samalla hän uusintaa näitä kertomuksia venäjän kielellä kertomalla niitä muun muassa piirikunnassa vieraileville turisteille ja koululaisille. Myös alla esitettävä Vyngy vada -lehdessä julkaistu teksti pohjautunee Ardeevin isän suulliseen esitykseen, vaikka sitä ei olekaan mainittu lehdessä. Tekstinä se edustaa ennemminkin kirjallista kuin suullista venäjää, mutta toisaalta siinä on monia viittauksia kansanomaisuuteen. Ardeevin julkaisemalla tekstillä on monia yhteisiä piirteitä niiden kertomusten kanssa, joita olen itse kerännyt Kolgujevin nenetsien parissa. Sekä keräämieni että Ardeevin esittämien kertomusten intertekstuaalinen ero nenetsinkieliseen perinteeseen on jo lähtökohtaisesti suuri silloin, kun perinnettä 
kerrotaan tai kirjoitetaan venäjäksi. Kokonaisuudessaan kuitenkin venäjänkielisissä kertomuksissa voidaan niin laajentaa kuin pienentääkin näitä eroja, enkä keskitykään tässä artikkelissa pohtimaan kielen luomaa juopaa sinänsä.

Esittelen alla Vyngy vadassa julkaistun tekstin, joka koostuu kahdesta osasta: ensimmäinen osa on eräänlainen johdanto, kun taas toinen osa esittää enemmän tai vähemmän rajatun kertomuksen. Kokonaisuudessaan näiden osien voidaan tulkita muodostavan lehden kontekstissa kerrontatilanteen tai -tilan, joka johdattaa kohti šamanistista kertomusmaailmaa. Näitä seuraa lyhyt osuus, jota voidaan luonnehtia resoluutioksi. Johdanto on otsikoitu Skazy o velikom šamen Purpee, Tarinoita suuresta Purpej-šamaanista:

НЕКОГДА НА ОСТРОВЕ КОЛГУЕВЕ ЖИЛ ВЫДАЮЩИЙСЯ ШАМАН ПУРПЭЙ. О НЕМ И ПОНЫНЕ ХОДЯТ ЛЕГЕНДЫ, А СТАРЫЕ НЕНЦЫ СТАРАЮТСЯ БЕЗ ЛИШНЕЙ НАДОБНОСТИ НЕ ПРОИЗНОСИТЬ ИМЯ НЕКОГДА ГРОЗНОГО КОЛДУНА. БЫЛ ШАМАН НЕБОЛЬШОГО РОСТА, ХУДОЩАВ ТЕЛОСЛОЖЕНИЕМ. ОЛЕНЕЙ ИМЕЛ НЕ ТАК МНОГО, ПРИМЕРНО ТЫСЯЧУ ГОЛОВ. ЗАТО НА МОРЕ НИКТО С НИМ НЕ МОГ СРАВНИТЬСЯ. В ОТЛИЧИЕ ОТ ДРУГИХ МОРСКИХ ОХОТНИКОВ, ПЛАВАЛ ПУРПЭЙ НА БОЛЬШОЙ ДЕРЕВЯННОЙ ЛОДКЕ И ЗНАЛ ВСЕ МОРСКИЕ ТЕЧЕНИЯ, НЕПЛОХО УПРАВЛЯЛСЯ С ПРИМОРСКИМ ПРЯМЫМ ПАРУСОМ. ЧАСТО, ВЫЙДЯ НА ОХОТУ СО СВОИМ ДРУГОМ - ТОЖЕ ШАМАНОМ - АНТИПОМ, ПО МНОГУ ДНЕЙ ДРЕЙФОВАЛ ВО ЛЬДАХ. ЛОДКУ ОНИ ВЫТАСКИВАЛИ НА ПЛАВУЧИЙ ЛЕД. НА ЭТОЙ ЖЕ ЛЬДИНЕ И РАЗДЕЛЫВАЛИ ДОБЫТЫХ МОРСКИХ ЗВЕРЕЙ - МОРЖЕЙ, ЛАХТАКОВ, НЕРП И БЕЛУХ.

ИНОГДА ШАМАНЫ ДОПЛЫВАЛИ ДО ОСТРОВА СЕН-ГЕЙСКИЙ, ЧТО НАХОДИТСЯ ЗА ПРОЛИВОМ, ОТ ОСТРОВА В ВОСЬМИДЕСЯТИ КИЛОМЕТРАХ. ИНОГДА ДРЕЙФОВАЛИ ВДОЛЬ ОСТРОВА. ТОГДА ДОБЫЧУ ОСТАВЛЯЛИ В ОПРЕДЕЛЕННОМ МЕСТЕ НА ПЕСЧАНОЙ КОСЕ.

ИМЕЛ ПУРПЕЙ И ТОРГОВЫЕ ОТНОШЕНИЯ С ЗАМОРСКИМИ ЗВЕРОБОЯМИ НОРВЕЖСКИМИ МОРСКИМИ ОХОТНИКАМИ. У НОРВЕЖЦЕВ В ОБМЕН НА ШКУРЫ ПЕСЦОВ, ЛИСИЦ, МОРСКИХ ЗВЕРЕЙ, ЖИР, И ОЛЕНЬЕ МЯСО БРАЛИ ЖИТЕЛИ ОСТРОВА ПОРОХ, СВИНЕЦ, МАСЛО КОРОВЬЕ, ИНОГДА - ВИНТОВКИ. ТОРГОВЛЯ ВСЕГДА ШЛА МИРНО И ДОБРОЖЕЛАТЕЛЬНО.

ИСКУССТВУ ШАМАНИЗМА ВЕЛИКИЙ ШАМАН, ПО РАССКАЗАМ ОСТРОВИТЯН, НАУЧИЛСЯ У СВОЕГО ДЕДА, ПРАВДА, НИКТО УЖЕ НЕ ПОМНИТ ИМЕНИ ЭТОГО ПРЕДКА. ПУРПЭЯ ЖЕ В МИРУ ВЕЛИЧАЛИ ИВАН ФИЛИППОВИЧ. ПРОЗВИЩЕ ЖЕ СВОЕ ОН ПОЛУЧИЛ ОТ СЛЕДОВ ОСПЫ. ОНА, КАК РЖАВЧИНА, ИЗЪЕЛА ОСПИНКАМИ ЕГО ЛИЦО (ПУРПЭЙ - РЖАВЫЙ).

ОДНАЖДЫ ГОРЯЧАЯ СТРУЯ КРОВИ РАНЕНОГО МОРЖА ПОПАЛА ШАМАНУ В ГЛАЗ. ОТ ЭТОГО ОН НАЧАЛ СЛЕПНУТЬ И К СТАРОСТИ СОВСЕМ ОСЛЕП. НО СИЛЫ СВОЕЙ НЕ УТРАТИЛ... (АРДЕЕВ 2011)

21 Kauan sitten Kolgujevin saarella eli merkittävä šamaani, Purpej. Hänestä kerrotaan vielä tänäänkin tarinoita, ja vanhemmat nenetsit välttävät turhaan lausumasta tämän suuren tietäjän nimeä. Hän oli lyhyt ja hintelä šamaani. Poroja ei ollut niin paljon, tuhantisen. Sitä vastoin merenkäynnissä häntä ei voinut verrata muihin. Toisin kuin muut merellä metsästävät, Purpej kulki suurella puisella veneellä, tunsi kaikki virtaukset ja ohjasi hyvin raakapurjetta. Usein kun hän kävi metsästämässä ystävänsä joka myös oli šamaani - Antipan kanssa, he saattoivat ajelehtia päiviä ajojäissä. Näillä jälautoilla he myös paloittelivat saalistamansa merinisäkkäät: mursut, partahylkeet, norpat ja valaat. Joskus šamaanit matkasivat aina Sengeiskin saarelle asti salmen toiselle puolelle, noin 80 kilometrin päähän saaresta. Joskus he ajelehtivat saaren rannoilla, ja silloin jättivät saaliinsa tietylle paikalle hiekkasärkille. Purpejlla oli 
kauppasuhteita merentakaisten, norjalaisten pyytäjien kanssa. Saarelaiset vaihtoivat norjalaisten kanssa naalin, ketun ja merinisäkkäiden nahkoja, rasvaa ja poronlihaa, ruutia, lyijyä, voita ja joskus kiväärejä. Kauppaa käytiin aina rauhanomaisissa ja ystävällisissä merkeissä. Šamanismin tämä suuri šamaani oppi saarelaisten kertoman mukaan isoisältään, jonka nimeä kukaan ei kylläkään enää muista. Purpejn maallinen nimi oli Ivan Filippovitš. Lisänimensä hän sai isorokon jäljistä. Isorokon arvet olivat kuin ruostetta hänen kasvoillaan (Purpej tarkoittaa ruosteinen). Kerran haavoittuneen mursun kuuma verisuihku osui šamaanin silmään, minkä vuoksi hän alkoi sokeutua ja lopulta menetti näkönsä täysin. Mutta voimiaan hän ei menettänyt...

Tämä johdanto-osuus koostuu Ardeevin tuntemien Purpejhin liittyvien tekstien lyhennelmistä tai referaateista. Samalla siinä esitellään kertomusmaailman pääasialliset ontologiset lähtökohdat: tekstissä on viittauksia šamanistisiin ja historiallisiin kertomusmaailmoihin. Suullisessa kerronnassa tämänkaltaiset aloitukset ovat tyypillisiä: johdanto-osuudet opastavat kuulijoita - tai kuten tässä tapauksessa, lukijoita - kertomusmaailmaan, mutta ne ovat yhtä lailla jo osa tätä maailmaa. Johdannossa viitataan myös Kolgujevin saarelaisten kertomuksiin: siinä käytetään ilmausta ПО РАССКАЗАМ ОСТРОВИТЯН, so. Saarelaisten kertoman mukaan. Tämä ilmaisu liittää Ardeevin muiden, aiempien tai tämänhetkisten kertojien ketjuun ja rakentavat folkloren tuntua (Bauman 2004: 27医28).

Johdanto-osuuden lopussa Ardeev kertoo Purpej-šamaanin ulkonäöstä ja tämän porojen lukumäärästä. Tämä taas edustaa nenetsien folklorelle tyypillistä tapaa esitellä sen toimijat. Usein folklorehahmojen nimet kertovat jo sinällään jotain tämän piirteistä tai ominaisuuksista: esimerkiksi epiikan sankarien nimet voivat olla sellaisia kuin Rautalakki, Seitsensyltäinen suksi, Kiehuva rauta, Haltianhärkä (Lehtisalo 1922: 86; Tereschenko 1980). Purpej onkin painotetusti šamaanin nimi, ja johdannossa mainitaan myös tämän maallinen tai tavanomainen nimi. Porojen lukumäärä ei kerro ainoastaan hahmon rikkaudesta tai köyhyydestä, mutta niin ikään tämän sosiaalisesta asemasta yhteisössä. Tuhatpäinen porotokka olisi nenetsien arkimaailmassa jo varsin mittava omaisuus: tällaiset liioittelumotiivit johdattavat tekstin tulkitsijoita kohti nenetsien perinteisiä kertomusmaailmoja, joissa sankareilla on poikkeuksetta tuhatpäisiä laumoja tai vaihtoehtoisesti ovat hyvin köyhiä. Esimerkiksi M. A. Castrénin 1840-luvulla muistiinmerkitsemä eeppinen runo, syudbabts, alkaa:

\begin{tabular}{|l|l|}
\hline Müü müsie & Pororaito jutaa \\
siu jurndier: & seitsemänsataa ihmistä \\
siu maro deata; & seitsemän nuukaa poromiestä \\
niedando müumnje & tietänsä pitkin \\
siu jaadna & seitsemän kävelee \\
uutusido waadarya: & vetävät kotapuurekeä: \\
siu häendalioda; & seitsemän Häendaliodaa; \\
njaatom pumnáh & ystäviensä takana \\
aaní jaadna jaadaa, & kulkee toisia kävelijöitä \\
ututsito waadarya: & vetävät kotapuurekeä: \\
siu siosidaej. & seitsemän Siosidaejta. \\
tarem müusiseatii. (Castrén 1940: 62) & Näin jutavat. \\
\hline
\end{tabular}

24 Tässä esimerkissä pororaidon omistajat, marodeatat, ovat raidossa jutaavien ihmisten määrän perusteella hyvin rikkaita, mutta tämän jäljessä seuraavat häendaliodat ja 
siosidaejt ovat köyhiä: he liikkuvat kävellen ja itse kotapuurekeä vetäen. Isäntien nimitys onkin sananmukaisesti käännettävissä 'kitsaat poromiehet', eikä Castrén ole tulkinnut sitä nimeksi, vaikka se olisi käsittääkseni mahdollista. Sen sijaan kaksi jälkimmäistä Castrén on tulkinnut nimiksi ja selittää ne muistiinpanoissaan niin, että häendalioda "förmodas beteckna en båge med obetydlig böjning på stocken" tarkoittanee jousta, joka kaareutuu alaosasta vähän" (хэндлЁ(сь) 'taipua vähän'). Siosidaejn kohdalle Castrén on kirjannut:

Sju S. Af Sioh '1) strupa, 2) hals (горло) på bågen - d.ä. ett tunnare st. På bågen för att bequämare kunna bäras i handen'. Siosida 'den som saknar en sådan böjng." "Seitsemän S., sanasta Sioh '1) kurkku, 2) jousen kurkku eli jousen kapeampi kohta, josta sitä on miellyttävämpi kantaa. Siosida 'se, jolla ei ole tällaista kaarta. Vaikka Ardeevin teksti ei edustakaan syudbatbs-genreä, viittaavat Purpejn luonnehdinnat vastaavanlaisiin kertomusmaailmoihin, joita on esitetty niin laulaen kuin kertoen eri nenetsien genrejen puitteissa.

Purpejn nimi liittyy hänen rokosta saamiinsa arpiin. Lisäksi Ardeev mainitsee johdannosa, että Purpej oli hyvä merenkävijä, ja että hänellä oli tapana ajelehtia metsästämään merinisäkkäitä kaukaisille saarille toisen kolgujevilaisen šamaanin, Antipan, kanssa. Vastaavanlaisia liioittelumotiiveja tapaa niin nenetsien epiikassa kuin šamanistisessa kerronnassakin. Tällaiset yksityiskohdat rakentavat myyttistä tai šamanistista kertomusmaailmaa.

Johdannossa myyttiset ja šamanistiset elementit sekoittuvat historiallisiin : nämä viittaavat (akateemisen) historiankirjoituksen aikoihin ja arjen jokapäiväisiin toimiin. Purpejn kerrotaan esimerkiksi käyneen kauppaa toisten merinisäkäsmetsästäjien kanssa. Johdanto-osuus rakentaa siis myös kuvaa miehestä, joka todella eli muutama vuosikymmen sitten, joka kävi merellä Ardeevin isoisän kanssa, ja joka sai oppinsa omalta isältään, vahvalta šamaanilta, jonka nimi on jo unohtunut ${ }^{1}$. Myös historiallisten yksityiskohtien voidaan nähdä viittaavan omanlaisiinsa kertomusmaailmoihin. Nämä ovat nenetsien omaehtoisen muistelun ja muistamisen kertomusmaailmoja, jotka rakentuvat vastaavin tavoin kuin muunkin omaehtoisen kerronnan maailmat. Merenkäyntiin, merinisäkäspyyntiin ja kaupankäyntiin liittyvä muistelu onkin sangen suosittua Kolgujevin nenetsien keskuudessa. Vaikka muutkin nenetsit ovat pyytäneet merinisäkkäitä, erityisesti kolgujevilaiset ja toisaalta myös novajazemljalaiset tunnetaan tästä ja se on hyvin suuri osa heidän identiteettiään. Krupnik (1976) on liittänyt merinisäkäspyynnin nenetsien ja nenetsejä aiemmin alueella asuneiden merinisäkäspyytäjien vuorovaikutukseen, mutta itse näkisin sen ennemminkin nenetsien ja venäläisten pomorien vuorovaikutuksen tuloksena.

Näiden tietojen myötä lukija on siis jo johdatettu šamanistiseen kertomusmaailmaan, jossa nenetsihahmot kykenevät tekoihin, joita tavalliset ihmiset eivät voi tehdä. Kertomusmaailman ontologiset lähtökohdat ovat tältä osin selkeitä ja Ardeev rakentaakin johdannossa hyvin perinteistä kertomusmaailmaa, jonka ero šamanistisiin perinteisiin on hyvin pieni, jos sitä on laisinkaan. Samalla Ardeev rakentaa myös historiallista kertomusmaailmaa, kuvatessaan šamaanin oikeana historiallisena henkilönä, joka todella eli Kolguejevin saarelaisten keskuudessa. Nämä erilaiset kertomusmaailmat eivät ole toistensa kanssa ristiriidassa, vaan ne pikemminkin kietoutuvat toisiinsa. 
Kertomuksessa kuvataan, miten Purpej-šamaani löytää kultaisen madon, selittää sen tarkoituksen saarelaisille ja ottaa sen haltuunsa. Ardeev on otsikoinut tekstin "ПУРПэй и золотой чЕРВь", Purpej ja kultainen mato:

КАК-ТО РАНО УТРОМ ПЕРЕПУГАННЫЕ ЖЕНЩИНЫ РАЗБУДИЛИ ШАМАНА. ОНИ БЫЛИ В УЖАСЕ ОТ УВИДЕННОГО: НА ПОРОГЕ ЧУМА ВЫТЯНУЛСЯ ЧЕРВЬ. НО ОН БЫЛ НЕ ПРОСТОЙ ЗЕМЛЯНОЙ, А ОГРОМНЫЙ И ЗОЛОТОЙ. С ЧЕШУЕК ДАЖЕ ШЕЛ СВЕТ. ВСЕМ СТАНОВИЛОСЬ СТРАШНО ПРИ ВЗГЛЯДЕ НА НЕГО.

НО ПУРПЭЙ НЕ ИСПУГАЛСЯ. ОН ВЗЯЛ ЧЕРВЯ В РУКИ, СОБРАЛ В КОЛЕЧКИ, БУДТО НАСТОЯЩИЙ АРКАН, И АККУРАТНО ПОЛОЖИЛ ПОД ПОРОГ, ПОД ДОСКИ. А ВСЕМ ОБЪЯСНИЛ, ЧТО СВЕРКАЮЩЕГО ЧЕРВЯ ПРИСЛАЛ ЕМУ ДРУГОЙ ШАМАН - НЕДРУГ. ЭТОТ ДИКОВИННЫЙ ЧЕРВЯК ДОЛЖЕН БЫЛ ЧЕРЕЗ АНУС ПРОНИКНУТЬ ВНУТРЬ ПУРПЭЯ И ПРОГРЫЗТЬ ЕГО. НО ВЕЛИКИЙ СТАРЕЦ ОКАЗАЛСЯ СИЛЬНЕЕ ЗЛА - ЕГО ДУХИ ЗАЩИТИЛИ ХОЗЯИНА ОТ ПОРЧИ И ВЕРНОЙ СМЕРТИ.

ПОТОМ, ПРИ ПЕРЕЕЗДАХ, ШАМАН ВСЕГДА ВОЗИЛ ВОЛШЕБНОГО ЧЕРВЯ САМ, НИКОМУ ЭТОГО ДЕЛА НЕ ДОВЕРЯЛ. А ПОСЛЕ ЧЕРВЬ ВДРУГ ПРОПАЛ. КУДА НИКТО НЕ ЗНАЛ. ПУРПЭЙ ПРО ТО НЕ РАССКАЗЫВАЛ, А СПРАШИВАТЬ ЛЮДИ поБОялись...

Kerran aikaisin aamulla pelästyneet naiset herättivät šamaanin. He olivat kauhuissaan näkemästään: kodan kynnyksellä lojui mato. Mutta se ei ollut tavallinen kastemato, vaan valtava ja kultainen. Sen suomuistakin tuli valoa. Kaikki kauhistuivat sen nähdessään. Mutta Purpej ei pelästynyt. Hän otti madon käteensä, keri sen kuin suopungin ja laittoi varovasti kynnyslaudan alle. Hän kertoi kaikille, että toinen, vihamielinen šamaani oli lähettänyt madon hänen luokseen. Tämän omituisen madon oli tarkoitus tunkeutua Purpejn sisälle hänen peräaukostaan ja jyrsiä hänet. Mutta suuri vanhus osoittautui pahaa voimakkaammaksi, hänen henkensä suojelivat isäntäänsä tuholta ja varmalta kuolemalta.

Myöhemmin muuttojen aikana šamaani kuljetti ihmematoa itse eikä uskonut tätä tehtävää kenellekään muulle. Mutta mato katosi yhtäkkiä, eikä kukaan tiedä, minne. Purpej ei suostunut kertomaan, eivätkä ihmiset uskaltaneet kysyä.

Kertomus on esimerkillinen nenetsien šamanistisen kertomusmaailman edustaja: siinä šamaanit riitelevät toistensa kanssa eri hahmoissa ilmestyvien apuhenkiensä välityksellä. Mato edustaa kertomuksessa yhtä apuhengen olomuotoa. Kertomusmaailmassa mato esitetään poikkeuksellisena: suurena ja kultaisena, mutta vastaavalla tavalla myös Purpejn rohkeus ja neuvokkuus edustavat poikkeavuutta. Tämä on tyypillistä šamanistiselle kerronnalle, jonka piirteitä olen käsitellyt toisaalla (Lukin 2011: 274医79; Lukin 2012.). Ardeevin tekstissä kertomusmaailma on kokonainen ja ehjä: sen toimijat toimivat odotuksenmukaisesti suhteessa rooleihinsa, jolle kertomuksen jännite perustuu. Šamaanin toimien salaperäisyys säilytetään tarinan loppuun asti.

31 Vertailtaessa Ardeevin kertomuskokonaisuutta Kolgujevilla keräämiini kertomuksiin, suurin ero on kehyksissä, jotka asettavat kertomusmaailman ontologiset lähtökohdat. Ero ei ole kertomusmaailmoissa sinänsä, vaan nimenomaan niissä tavoissa, joilla kertomusmaailman, kerrontatilanteen ja keskustelu- tai muun kontekstin suhteet rakennetaan. Asian voi ilmaista niinkin, että ero on kertomusmaailman arvioinnissa (Siikala 1984). 


\section{Selvännäkijä, hypnotisoija}

32 Kolgujevin saarelaisten suhde šamanistisiin perinteisiin ei ole yhtä yksioikoinen tai helppo kuin mantereen kaupungeissa asuvalla älymystöllä. Heidän šamaaneja tai šamanismia koskevia kertomuksiaan kehystää usein epäusko tai epäilys. Toisin sanoen kertojat etäännyttävät itsensä šamanistisista kertomusmaailmoista ja maksimoivat etäisyyden šamanistiseen folkloreen (ks. Lukin 2012). Totuudellisuus rakentuu epäilyksen kautta, mikä on tyypillistä memoraateille tai yleisemmin henkilökohtaiselle kerronnalle (Bennett 1999: 14医25). Kolgujevilaisten šamaaneja koskevassa kerronnassa huomiota herättää myös šamaanien naurunalaiseksi tekeminen. Vaikka tällainen naurunalaiseksi tekeminen on ollut todennäköisesti tavanomaista aiemminkin, nykykerronnassa huomiota kiinnittää sen samankaltaisuus neuvostoaikaisen uskonnonvastaisen propagandan kanssa. Naurunalaiseksi tekeminen oli yksi propagandan käyttämistä ja suosituimmista välineistä, ja kolgujevilaiset kertojat näyttävät omaksuneen sen osaksi kerrontaansa. (Pospielovski 1988; Forsyth 1992:

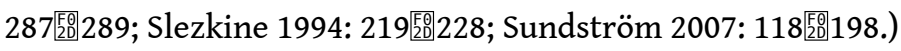

Kun Ardeev ja näkemykseni mukaan suurin osa nenetsiälymystöstä rakentaa šamanistista kertomusmaailmaa ja kietoo sen ympärille historiallisia kertomusmaailmoja, he haluavat korostaa, että tämä todella tapahtui. Mutta sen sijaan niin sanotut tavalliset ihmiset Kolgujevilla rakentavat yhteyksiä šamanistisiin ja historiallisiin kertomusmaailmoihin kyseenalaistaakseen historiassa tunnettujen šamaanien toimintaa. Tälle on useita syitä ja neuvostoaikainen uskonnonvastainen propaganda on varmasti yksi niistä. Toinen syy löytyy šamanistisesta perinteestä. Aiemmin šamanistisissa yhteisöissä šamaanit oli tapana piilottaa ulkopuolisilta ja tietoa šamaaneista ja heidän erityisominaisuuksistaan pidettiin yhteisön sisäisenä tietona, minkä lisäksi heitä vertailtiin keskenään jatkuvasti. Oheisesta esimerkistä käy selvästi ilmi kolgujevilaisen kerronnan kyseenalaistava tendenssi:

И(НФРОМАНТ): ТАКОЙ-ЖЕ ШАМАН ПРОСТО ЧЕЛОВЕК, ПРОСТО ОБЛАДАЕТ ЭТИМ, КОТОРЫМ, В ОБЩЕМ КОЛДОВСТВОМ КОТОРЫЙ МОЖЕТ, ТАКИХ И ЛЮДЕЙ СЧИТАЛИ КОТОРЫЕ ГИПНОЗОМ ХОРОШО ВЛАДЕЛ. В ОБЩЕМ, БЫВАЕТ ТАК, ЯСНОВИДЕЦ ВОТ ДАЛЕКО, ДАЛЬШЕ ВПЕРЕД УЖЕ ВИДИТ, ЗНАЕТ, ВОТ ТАКОГО ЧЕЛОВЕКА ТОЖЕ СЧИТАЛИ ШАМАНОМ. ВОТ, ДОПУСТИМ, ЗА НЕДЕЛЮ ВПЕРЕД УЖЕ НЕКОТОРЫЕ РАЗ УЖЕ ВИДНО БЫЛО ЧТО, ТО ЭТО СЛУЧИТСЯ, ТАКОЙ СЛУЧИТСЯ ВИДЬ. И ВСЕМ СКАЖЕТ И ЕМУ ВСЕ ВЕРЯТ. КОГДА УЖЕ НАСТАНЕТ ЭТО ВРЕМЯ ЧТО, ТОЧНО ТАКОЕ-ЖЕ БУДЕТ ЯВЛЕНИЕ ПОЯВИТСЯ. ЗНАЧИТ, СКАЖЕТ-ТО, ОСОБЕННО БЫВАЕТ ЧТО ПРЕДУПРЕДИТ ЛЮДЕЙ - ТАКИХ ЛЮДЕЙ СЧИТАЮТ ЧТО ШАМАНОМ.

К(АРИНА) Л(УКИН): ПОНЯТНО. А ВЫ СКАЗАЛИ, ЧТО У ВАС ПРАОТЕЦ ХОРОШИЙ ШАМАН БЫЛ...

И: ДА, ДА. ОН ВИДЬ НА ГЛАЗАХ ЛЮДЕЙ ГИПНОЗ СДЕЛАЛ НАВЕРНО [..] ТОЖЕ ВИДЬ, ТОЖЕ ГИПНОТИЗЕТ. СВАДЬБА БЫЛА. ТАМ ВОКРУГ ТОГДА КРУЖИЛИСЬ НА ОЛЕНЯХ, ГОНКИ БЫЛИ. Я ВИДЕЛ ТРИ СВАДЬБЫ ВИДЕЛ ЛИЧНЫЕ, ТАКИЕ В ТУНДРЕ РАНЬШЕ ВИДЕЛ, ТАК ВИДЬ, КАК БОЛЬШОЙ ПРАЗДНИК В ОБЩЕМ. ТОГДА ОН, ПРАДЕД-ТО У НАС ДОКАЗАЛ, ЧТО Я МОГУ. ОН ПРОТКНУЛ ЗДЕСЬ НОЖОМ И ЗДЕСЬ ТОЖЕ ПОЛНОСТЮ НОЖОМ И СЮДА ЭТОТ ТЯГАЯ ВОТ ЭТОТ САНИ - СЮДА ПРОТКНУЛ И ЭТИ. А ТАМ ЭТИ БЫЛИ, ТОЛЬКО УПРЯЖЬ, ПУСТОЙ УПРЯЖЬ ТЯГАЯ СЮДА НАТЯНУЛ ОН НА САНИ ШЕЛ ВПЕРЕДИ ТАК, И ВЕСЬ УПРЯЖЬ ВИДЬ, КАК ЗАПРЯЖЁННЫЙ ПОДНЯЛСЯ САМ КАК НА ОЛЕНЯХ ПОЛНОСТЬЮ, КАК НА ОЛЕНЯХ И ПОМЧАЛИСЬ ВОКРУГ ЧУМОВ, ДАЖЕ ЭТИ, 
ТОГДА УКРАШЕНИЕ ТОГДА ОЧЕНЬ КРАСИВЫЕ БЫЛИ, УПРЯЖЬ ЭТО. ВСЕ ПРЯМО ЗВОНОМ ЕХАЛИ БЕЗ ОЛЕНИ, КАК БУДТО ОЛЕНИ ЗАПРЯЖЁННЫЕ НА НЕГО КАК БУДТО, А ОЛЕНИ НЕВИДНО, ВОКРУГ ЧУМОВ. ВРОДИ СЕМЬ КРУГОВ ОН СДЕЛАЛ, ПОЛНЫЕ САНИ И ЧЕРЕЗ ЭТО ВИДЬ МЕСТО, ЗДЕСЬ ПРОТЯНУЛ И ПОТОМ ТЯГАЕТ ТУДА НАТЯНУЛ ГДЕ ЭТИ ДЫРКИ ДЕЛАЛ ТАМ [..] ВОТ ЭТО УЖЕ САМАН, ОН ГИПНОТИЗЕТ, ГИПНОЗ И РАЗ ШАМАН-ТО.

I(nformantti): Šamaani on tavallinen ihminen, joka vain osaa, joka pystyy harjoittamaan noituutta. Sellaisia ihmisiä pidettiin šamaaneina, jotka taisivat hyvin hypnoosin. Šamaani voi esimerkiksi olla selvännäkijä, hän näkee kauas eteenpäin, tietää mitä on tulossa ja sellaista ihmistä pidettiin šamaanina. Sanotaan vaikka että viikon eteenpäin, niin tapahtui useita kertoja, että näki viikon eteenpäin. Ja šamaani kertoo kaikille ja kaikki uskovat. Ja kun aika tulee, juuri sellaista tapahtuu. Šamaani voi esimerkiksi kertoa, vaikka varoittaa ihmisiä ja sellaisia ihmisiä pidetään šamaaneina.

K(arina) L(ukin): Selvä. Kerroitte, että isoisänne oli hyvä šamaani...

I: Kyllä, kyllä. Hän varmaankin hypnotisoi ihmisiä vain silmiin katsomalla. [..] Hän myöskin hypnotisoi siis. Kerran oli häät. Hääpaikan ympärillä ajettiin poroilla ympyrää; oli kilpailut. Olen itse osallistunut kolmiin häihin henkilökohtaisesti; näin sellaisia ennen tundralla ja ne olivat suuria juhlia. Ja silloin isoisämme näytti, että minä osaan. Hän löi tänne puukolla ja täältä kokonaan läpi löi puukolla ja täältä, ja reen laittoi. Ja siellä oli vain valjaat, pelkkien valjaiden kanssa veti reen tänne ja kulki reellä eteenpäin, kaikki valjaat ja valjastettuna nousi niin kuin poroilla, ihan kuin poroilla pinkoivat kotien ympärillä. Ja silloin valjaiden koristelutkin olivat kauniit. Ja niin menivät äänekkäästi ilman poroja ikään kuin siinä olisi ollut porot valjastettuna ympäri kotia, mutta poroja ei näkynyt. Taisi tehdä seitsemän kierrosta täysillä reillä ja läpi tämän paikan, veti tänne ja sinne, missä teki reiätkin. Ja sellainen on šamaani, hypnotisoi, hypnoosia, kun kerran on šamaani.

Esimerkki on ote pitkähköstä haastattelustani kolgujevilaisen perinteentaitajan kanssa. Jo ennen tässä esiteltävää katkelmaa haastateltava oli esittänyt šamaanit ihmisinä, jotka hallitsevat tekniikoita, joiden avulla voi huiputtaa ihmisiä: he osaavat hypnotisoida tai tehdä silmänkääntötemppuja. Olen myös keskeltä haastattelua poistanut pitkän kohdan, jossa haastateltava rinnastaa šamaanit sirkusten taikureihin ja muistelee omia kokemuksiaan sirkuksissa. Vaikka olen stilisoinut tekstiä niin, että se olisi helppolukuisempaa - muun muassa poistanut toistoa ja keskeneräisiksi jääneitä sanoja - näyttäytyy tämä haastattelukatkelma selvästi puhekielisenä ilmaisuna ja suullisena kerrontana. Se heijastuu edelleen epäselvempinä lauserakenteina ja esimerkiksi indeksikaalisina ilmauksina, jotka jäävät pelkässä tekstissä epäselväksi. Informantti osoitti rintakehäänsä ja vatsan seutuansa kertoessaan, mihin šamaani löi puukollaan reiät kiinnittääkseen niihin valjaat.

Kun pidetään mielessä katkelmaan tekemäni poistot, yllä olevan kertomuksen johdanto-osuus on huomattavasti kirjallisen kertomuksen johdanto-osuutta pitempi, mutta myös kehyksenä täysin erilainen. Siinä korostetaan šamaanin tavallisuutta ja sitä, että šamaanin hallitsema noituus on ainoastaan tekninen taito, jonka šamaanit ovat hankkineet. Kertoja kyllä korostaa, että šamaaneihin luotettiin esimerkiksi selvännäkijöinä ja että heidän ennustuksillansa oli tapana toteutua. Kysyessäni kertojan isoisästä tämä siirtyy johdannon kehyksistä kohti kertomusmaailmaa eli häitä, joissa isoisä halusi todistaa taitonsa. Myös tällaisella kerronnalla on pitkät perinteet, ja se sijoittuu osaksi šamanismin ympärillä kiertävää perinnettä, jonka puitteissa tieto šamaanien kyvyistä ja voimista on levinnyt yhteisössä (ks. Lukin 2012). Etnografisissa teksteissä ja matkakuvauksissa annetaan ymmärtää, että šamaanit esittelivät henkisiä 
voimiaan tai apuhenkiään toistuvasti esimerkiksi viiltelemällä itseään. Esimerkiksi Castrén on kirjoittanut:

Muutama kuukausi sitten erääseen Timanin tundran kotaan kokoontui kolme samojedia ja yksi venäläinen. Yksi samojedi oli perillä taadibeiden salaisuuksista. Tavanomaiseen hurmostilaan jouduttuaan taadibe käski kesken toimituksen ampumaan itseään panostetulla kiväärillä. Toinen samojedeista totteli käskyä, mutta luoti ei osunut tai - kuten kerrottiin - se kimmahti takaisin ruumiista. Kivääri ladattiin uudelleen ja toinenkin samojedi laukaisi, mutta menestys oli yhtä huono. Venäläinen hämmästeli tätä, panosti kiväärin, ampui ja - osui. Samojedi kuoli heti paikalla. Kaninin tundralla tapasin joukon virkamiehiä, jotka oli lähetetty tutkimaan asiaa. En tiedä tutkimusten tuloksia, kertomukseni perustuu yleisiin huhupuheisiin. (Castrén 1967: 140-141.)

Informantti tunteekin selvästi tämän perinteen hyvin ja hänen kertomuksensa sijoittuu kiistatta juuri tällaiseen šamanistiseen kertomusmaailmaan, jossa šamaani haluaa osoittaa yhteisölle taitonsa ja voimansa. Kertomuksessa šamaani onnistuu hämmästyttämään hääväkeä kiinnittämällä valjaat itseensä ja vetämällä rekeä hääkodan ympäri. Niinpä tässä kertomusmaailmassa šamaania tai šamanismia kokonaisuutena ei nolata kuten Castrénin 1840-luvulla kuulemassa tarinassa, jossa šamaani lopulta kuolee venäläisen ampumaan luotiin. Mutta kertoja kiistää šamaanin taitojen yliluonnollisen ja šamanistinen perustan kertomusmaailman ulkopuolella sekä johdanto-osuudessa että arvioinnoissa toistamalla šamaanin temppujen perustuvan hypnoosiin. Niinpä kerrontatilanteen kehykset tuntuvat kieltävän kertomusmaailman ontologiset oletukset ja korostavan kerrontatilannetta ympäröivän yhteiskunnallisen kontekstin ontologisia oletuksia.

\section{Perinteen kertominen 2000-luvun Venäjän pohjoisessa}

Molempien yllä esittämieni kertomusten laajempi yhteiskunnallinen konteksti on sama sosialismin jälkeinen Venäjän pohjoinen, jossa nenetsinkielistä kerrontaa kuulee enää harvoin. Tästäkin huolimatta sekä nenetsien omissa yhteisöissä että niiden ulkopuolella, erityisesti Nar'yan-Marin kaupungissa, ollaan kiinnostuneita perinteen sisällöistä. Kuten kaikissa Venäjän pohjoisissa piirikunnissa, myös Nenetsiassa alkuperäiskansoja esitetään eksoottisina toisina, jotka antavat alueelle sen erityisyyden. Neuvostoaikoina tämän kulttuurisen erityisyyden esittäminen kehittyi laajamittaiseksi kulttuuriteollisuudeksi, jonka toimijat liikkuivat joustavasti keskuksen julkisuuden ja paikallistason tilaisuuksien välillä. Omaa kulttuuriperintöä esitettiin siis sekä neuvostokansalaisille kokonaisuudessaan että omalle etniselle ryhmälle. Neuvostoaikainen kulttuuriperintö oli luonteeltaan esteettisesti ja poliittisesti valikoitunutta ja tiedostetun kohosteista estradiperinnettä; esimerkiksi uskonnollisia teemoja ei käsitelty, ellei näin tehty kielteisessä valossa.

Neuvostoliiton hajoamisen jälkeen estradiperinne on jatkunut Nenetsiassa, minkä lisäksi kulttuuria on alettu esittää lehdissä, radiossa ja televisiossa. Monien esitysten estetiikka on edelleen samankaltaista kuin neuvostoaikoina: esityksissä viitataan vallankumousta edeltävään nenetsien materiaaliseen ja henkiseen kulttuuriin esimerkiksi perinteisiä pukuja, nenetsien folkloren motiiveja tai kotaa esittämällä. Esitysten sisällöt eivät ole kuitenkaan enää niin valikoituneita, ja etenkin šamanismiin viittaavaa tematiikkaa on alettu tuoda voimakkaammin esiin. Se on selvästi eksoottinen ja kiinnostava teema, josta monet, etenkin ulkopuoliset, haluavat kuulla enemmän. 
39 Tässä mielessä sitä voidaan pitää kulttuuriperintönä (heritage), joka viimeaikaisissa tutkimuksissa on määritelty valikoiduksi tai rajatuksi ja esiin nostetuksi kulttuurin osaksi, jonka arvo nimenomaan kulttuuriperintönä on myönteissävytteinen. Kulttuuriperintötoiminnan taustalla on usein jonkin kulttuurin tai ryhmän esittäminen ja sikäli sen identiteetin keskeisten piirteiden määrittäminen. Tällaista toimintaa on pidetty usein älymystön toimintana, mutta on tärkeää havaita, että myös älymystön ulkopuoliset, niin sanotut tavalliset ihmiset valikoivat, nostavat esille ja arvottavat omaa kulttuuriaan ja puhettaan jatkuvasti (ks. Bendix 2000; Klein 2006).

40 Filipp Ardeevista on tullut piirikunnassa henkilö, joka usein sekä esittää šamaania estradeilla että kertoo šamaaneista ulkopuolisille. Ardeev tuntee šamanistisen perinteen henkilökohtaisesti vanhempiensa ja isovanhempiensa kautta, minkä lisäksi hän on perehtynyt aiheeseen kirjallisuuden kautta. Kertoessaan šamanismista tai yksittäisistä šamaaneista hän viittaa tuntemaansa suulliseen perinteeseen, kuten yllä esitetyssä esimerkissä. Se luo kiistatta auktoriteettia perinteen välittäjälle. Nenetsien eeppiseen perinteeseen viittaavat šamaanin nimitys ja tämän luonnehdinnat lähentävät Ardeevin kerrontaa nenetsien perinteeseen.

41 Hänen kertomuksensa kehystyy todeksi, mutta se kehystyy myös voimakkaasti šamanistisen kertomusmaailman ontologioita tukevaksi. Kerronta ei luo mielikuvaa ainoastaan Purpej-šamaanista todellisena historiallisena henkilönä, vaan myös mielikuvaa šamanismin metafyysisten lähtökohtien totuudellisuudesta. Muiden kolgujevilaisten kerronnassa näin tapahtuu ainoastaan poikkeuksellisissa tapauksissa. Kertomusten kertomusmaailmat ovat usein yhtä eheitä kuin Ardeevin kertomusmaailmassakin, mutta kerronnan kehykset kiistävät usein, monin eri keinoin, šamanistisen maailmankuvan totuudellisuuden. Esittämässäni esimerkissä šamanistinen ontologia kiistetään hypnoosiin vetoamalla, mutta kiistää voidaan myös toteamalla, että šamaanit olivat silmänkääntäjiä ja huijareita (obmanštšiki) tai implisiittisemmin esimerkiksi naureskelemalla kerrotulle.

42 Molemmissa esittämissäni kertomuksissa voidaan näin ollen havaita jatkuvuuksia nenetsien perinteeseen, mutta ne kiinnittyvät myös neuvostoaikaiseen nenetsien perinteen esittämisen tapoihin - toisistaan poikkeavin tavoin. Kertomus Purpejsta on neuvostoaikana koulutuksensa saaneen älymystön edustajan tyypillinen kertomus, joka korostaa šamanismin historiallisuutta - se on ilmiö, josta kerrotaan menneessä aikamuodossa. Ardeevin kertomuksessa uutta on ilmiön arvottaminen positiivisesti. Siinä - ja muussakin 2000-luvun älymystön toiminnassa - šamanismi nostetaan esiin myönteisessä valossa, kulttuuriperintönä. Šamaanit ja painottaen vielä voimakkaat ja hyviä kauppakontakteja ja erityistaitoja omanneet šamaanit ovat sellaisia hahmoja, joita älymystön on mielekästä nostaa esille omasta menneestä kulttuuristaan.

43 Kolgujevilaisten šamaanikertomukset asettuvat taas neuvostoaikaisen ateistisen diskurssin jatkumolle. Ateistisessa propagandassa šamaaneja ja muita uskonnollisia auktoriteetteja pilkattiin ja halveksittiin, ja heidän auktoriteettiaan pyrittiin vähentämään erityisesti osoittamalla heidän toimintansa perustuvan huijaukseen ja erilaisiin psykologisiin tekniikoihin. On mahdollista, että tämänkaltainen diskurssi on omaksuttu osaksi tapaa, jolla šamaaneista kerrotaan nimenomaan ulkopuolisille, jollaiseksi minutkin voi lukea. Se on turvallinen tapa välittää tietoa šamaaneista kiinnittymättä itse uskonnollisen metafysiikan kannattajaksi. Kuten Castrénin päiväkirjoista poimittu esimerkki osoittaa, šamanismin kiistämiseen keskittyvällä kerronnalla on juurensa syvemmällä kuin neuvostoaikojen ateistisessa propagandassa. 
Omista taidonosoituksistaan kärsivät tai uhoamisesta jopa kuolevat šamaanit ovat osa šamanismin perinnettä.

\section{Lopuksi} perinteen, esittämisessä on tavallisten kolgujevilaisten ja nenetsiaälymystön välillä 2000-luvulla. Tapa, jolla šamanismista puhutaan tai kerrotaan paikallisella tasolla, on jännitteinen ja vaikea: neuvostoaikaiset ateistiset mielikuvat ja käsitykset nenetsien perinteisestä kulttuurista jälkeenjääneenä ja paheksuttavana on omaksuttu joko täysin tai vähintään diskursiivisena käytäntönä. Sen sijaan älymystö tapaa puhua šamanismista vaivatta ja jopa mielellään. Heille se on osa nenetsien kulttuuriperintöä, jonka he arvottavat myönteisesti. Älymystölle šamanistiset kertomusmaailmat edustavat jonkinlaista varastoa, jota voidaan hyödyntää Naryan-Marin kaupungissa silloin kun nenetsiyttä esitellään ulkopuolelta tuleville vieraille tai kun koululaisille pitää opettaa jotain nenetsien perinteistä ja kulttuurista. Tällaisena kulttuuriperintönä šamanismi on eksoottinen ja kaikkia kiinnostava aihe.

Nämä asenteet heijastuvat nenetsien kerrontaan kehyksinä, jotka arvottavat itse kertomuksen. Tyypillisesti nenetsien esittämien kertomusten kertomusmaailmat ovat sinänsä eheitä ja niiden sisällöt palautuvat vaivatta nenetsien suulliseen perinteeseen ja šamanismiin. Näissä kertomusmaailmoissa šamaanit ovat yhteisössään poikkeuksellisia voimiensa ja nokkeluutensa ansiosta, mutta heillä on myös muita hyviä ominaisuuksia. Kertomusmaailmat viittaavatkin nenetsien aiemmin kuulemiin ja hahmottamiin kertomusmaailmoihin, ja ne palautunevat niin eeppisiin lauluihin kuin proosakertomuksiinkin. Kertomusmaailmoja tuotetaan 2000-luvulla nenetsinkin kielellä, mutta pääosin venäjäksi sekä nenetsien omassa vuorovaikutuksessa että piirikuntaan saapuville ulkopuolisille. Silti merkityksellistä on ymmärtää, että itsessään šamanistista perinnettä, esimerkiksi rituaalisia lauluja, ei esitetä venäjäksi. Vaikka siis kertomusmaailmojen intertekstuaalinen ero nenetsien perinteeseen on hyvin pieni sisällön tasolla, jo kielenvaihdoksen takia ero on huomattava. Tätä eroa pyritään joko pienentämään tahi suurentamaan kehyksillä, joita kertojat rakentavat kerrontatilanteessa. Viittaukset muihin šamanistisiin kertomusmotiiveihin eli kertomusmaailmoihin ja perinteen välittymisprosesseihin sekä historiallisen šamaanin elämään pyrkivät pienentämään kertomuksen eroa nenetsien suulliseen perinteeseen. Sen sijaan šamaanin toiminnan kyseenalaistamisen avulla laajennetaan etäisyyttä šamanismiin ja rakennetaan mielikuvaa šamanismista ja šamaaneista naurettavina.

Molemmat kehykset sijoittavat šamanismin menneisyyteen ja kiistävät sen olemassaolon elävänä perinteenä tämän päivän nenetsien parissa. Molemmat heijastavat niin ikään kokonaisen kieli- ja perinneyhteisön murrosta mutta ratkaisevat suhteensa murrosta edeltäneeseen perinteeseen poikkeavin tavoin. 

Next”, in Anttonen, Pertti J., Siikala, Anna-Leena, Mathisen, Stein R. and Magnusson, Leif (eds.), Folklore, Heritage Politics and Ethnic Diversity,A Festschrift for Barbro Klein. Botkyrka: Multicultral Centre, p. 37-54.

BENNETT Gillian, 1999, Alas, poor ghost! Traditions of belief in story and discourse, Logan, Utah: Utah State University Press.

вцосн Alexia, 2004, Red Ties and Residential Schools: Indigenous Siberians in a Post-Soviet State, Philadelphia (PA): University of Pennsylvania Press.

BRIGGS Charles L. \& Bauman Richard, 1992, "Genre, Intertextuality, and Social Power", Journal of Linguistic Anthropology 2(2), p. 131-172.

CASTRÉN M. A., 1940, Samojedische Volksdichtung, Gesamm. von M. A. Castrén. Herausgegeben von T. Lehtisalo. Suomalais-Ugrilaisen Seuran Toimituksia LXXXIII. Helsinki : Suomalais-Ugrilainen Seura.

CASTRÉN M. A., 1967, Tutkimusmatkoilla pohjolassa, Suom. Joki, Aulis J. Helsinki: Kustannusosakeyhtiö Tammi.

DIVNYE, 2013 = « ДИВНЫЕ МЕЛОДИИ ТУНДРЫ », НАРЬЯНА ВЫНДЕР 38. 11.4.2013.

Online http://nvinder.ru/article/vypusk-no-38-19950-ot-11-aprelya-2013-g/442-

divnye-melodii-tundry

ERMAKOV et al., 2003 = ЕРМАКОВ, « ВОСТРЕБОВАННОСТЬ РОДНОГО ЯЗЫКА НЕНЕЦКИМ НАСЕЛЕНИЕМ НАО. НЕКОТОРЫЕ ИТОГИ СОЦИОЛОГИЧЕСКОГО ОПРОСА », in МЕНШАКОВА, Е. Г. (РЕД.), МАТЕРИАЛЫ НАУЧНО-ПРАКТИЧЕСКОЙ КОНФЕРЕНЦИИ “НЕНЕЦКАЯ ПИСЬМЕННОСТЬ И РАЗВИТИЕ НАЦИОНАЛЬНЫХ ТРАДИЦИИ НАРОДА”,НАРЬЯН МАР : НЕНЕЦКИЙ ОКРУЖНОЙ КРАЕВЕДЧЕСКИЙ МУЗЕЙ, 181-183.

FORSYTH James, 1992, A History of the Peoples of Siberia. Russia's North Asian Colony 15811990, Cambrige: Cambridge University Press.

GRANT Bruce, 1995, In the Soviet House of Culture. A Century of Perestroikas,Princeton: Princeton University Press.

HANZEROVA Irina, $2013=$ ХАНЗЕРОВА ИРИНА, «СПОМНИ И СПОЙ ЖИЗНИ РОДА СВОЕГО », НАРЬЯНА ВЫНДЕР 26. 14.3.2013

Online http://nvinder.ru/article/vypusk-no-26-19938-ot-14-marta-2013-g/232vspomni-i-spoy-zhizn-roda-svoego

61 HUMPHREY Caroline, 1983, Karl Marx Collective. Economy, society and religion in a Siberian collective farm, Cambridge: Cambridge University Press.

2 ITOGI... 2004 = ИТОГИ ВСЕРОССИЙСКОЙ ПЕРЕПИСИ НАСЕЛЕНИЯ 2002 ГОДА (14 Т), ТОМ 4 : 1, НАЦИОНАЛЬНЫЙ СОСТАВ И ВЛАДЕНИЕ ЯЗЫКАМИ, ГРАЖДАНСТВО,МОСКВА : ФЕДЕРАЛЬНАЯ СЛУЖБА ГОСУДАРСТВЕННОЙ СТАТИСТИКИ.

KLEIN Barbro, 2006, "Cultural Heritage, the Swedish Folklife Sphere, and the Others", Cultural Analysis, 5, p. 57-80.

КRUPNIK I. I., 1976 = « СТАНОВЛЕНИЕ КРУПНОТАБУННОГО ОЛЕНЕВОДСТВО У ТУНДРОВЫХ НЕНЦЕВ », СЕВЕТСКАЯ ЭТНОГРАФИЯ, 2 : 57-69.

KUPRIJANOVA Z.N., = КУПРИЯНОВА, З.Н., ЭПИЧЕСКИЕ ПЕСНИ НЕНЦЕВ, МОСКВА : НАУКА.

LEHTISALO T., 1922, Jurakkisamojedien lauluista. - Kalevalaseuran vuosikirja 2, p. 82-102. 
ПРАКТИЧЕСКОЙ КОНФЕРЕНЦИИ “НЕНЕЦКАЯ ПИСЬМЕННОСТЬ И РАЗВИТИЕ НАЦИОНАЛЬНЫХ ТРАДИЦИИ НАРОДА”, НАРЬЯН МАР : НЕНЕЦКИЙ ОКРУЖНОЙ КРАЕВЕДЧЕСКИЙ МУЗЕЙ, 181-183

71 POSPIELOVSKY Dmitri, 1988, Soviet Antireligious Campaigns and Persecutions. Volume 2 of A History of Soviet Atheism in Theory and Practice, and the Believer, Hampshire and London: Macmillan Press. КРУГЛОГО СТОЛА », in МЕНШАКОВА, Е. Г. (РЕД.), МАТЕРИАЛЫ НАУЧНО-ПРАКТИЧЕСКОЙ КОНФЕРЕНЦИИ “НЕНЕЦКАЯ ПИСЬМЕННОСТЬ И РАЗВИТИЕ НАЦИОНАЛЬНЫХ ТРАДИЦИИ НАРОДА”, НАРЬЯН МАР : НЕНЕЦКИЙ ОКРУЖНОЙ КРАЕВЕДЧЕСКИЙ МУЗЕЙ, 132-135. SERGEEV M. А., 1955 = СЕРГЕЕВ, М.А., НЕКАПИТАЛИСТИЧЕСКИЙ ПУТЬ РАЗВИТИЯ МАЛЫХ НАРОДОВ СЕВЕРА, МОСКВА : И.Э. ИМЕНИ МИКЛУХО-МАКЛАЯ 18(2), p. 41-60. 
VAHTIN Nikolaj Borisovič, 2001 = ЯЗЫКИ НАРОДОВ СЕВЕРА В ХХ ВЕКЕ. ОЧЕРКИ ЯЗЫКОВОГО СДВИГА, САНКТ-ПЕТЕРБУРГ : ЕВРОПЕЙСКИЙ УИВЕРСИТЕТ В САНКТ-ПЕТЕРБУРГЕ.

WILCE James M., 2009, Crying shame: metaculture, modernity, and the exaggerated death of lament, Malden: Wiley-Blackwell.

YOUNG Katherine Galloway, 1987, Taleworlds and Storyrealms. The phenomenology of Narrative, Hingham, Lancaster, Dordrecht: Kluwer Academic Publishers Group.

\section{NOTES}

1. Tosiasiassa nimi ei ole täysin unohtunut, koska Purpejn tavallisen nimen patronyymista, Filippovitš, voidaan päätellä hänen isänsä nimeksi Filipp. Tämä on tunnettu hahmo saarelaisten muistelussa, ja on outoa, jos Ardeev ei tunne häneen liittyvää muistelua.

\section{RÉSUMÉS}

La plupart des communautés minoritaires du Nord de la Russie ont connu un changement de langue, passant de leur langue autochtone au russe. De plus, bien d'autres changements, depuis la sédentarisation jusqu'à la transformation du rôle de la religion, se sont produits parmi les citoyens soviétiques. Cet article s'interroge sur la nature de la tradition orale, surtout chamanique, après ces mutations et notamment après la propagande athée dans le Nord, surtout parmi les Nénetses. Il s'appuie aussi bien sur des travaux de terrain faits sur l'île de Kolguev, dans la mer de Barents, que sur des travaux d'archives. Les narrateurs de la tradition ont tendance en même temps à minimiser et à souligner le décalage entre leur narration et la tradition nénetse. Les décalages découlent surtout des cadres de la narration. En même temps, les narrateurs définissent implicitement leur rapport au chamanisme.

Suurin osa Venäjän pohjoisista vähemmistöyhteisöistä vaihtoi myöhäisinä neuvostovuosina oman äidinkielensä venäjään, minkä lisäksi elämäntavoissa tapahtui muitakin suuria muutoksia paikalleen asettumisesta uskonnon aseman muutokseen. Artikkelissa pohditaan, millaista suullinen, erityisesti šamanistinen perinne on kielenvaihdon ja ateistisen propagandan jälkeen nenetsien parissa. Artikkelin aineisto on kerätty etnografisessa kenttätyössä Kolgujevin saarella, Barentsin merellä. Lisäksi käytetään sanomalehti- ja arkistoaineistoja. Perinteen kertojat pyrkivät sekä rakentamaan jatkuvuuksia nenetsinkieliseen perinteeseen että tekemään eroja siihen. Näin he tulevat myös määrittäneeksi omaa suhtautumistaan šamanismiin. Pääasiallinen etäisyyden tai läheisyyden luomisen keino on kerronnan kehystäminen. 
Most of the northern minority communities of Russia went through a language shift from their own indigenous languages to Russian. In addition, many other changes, from sedentarisation to the change of the role of religion, took place among Soviet citizens. This article discusses the nature of oral, especially shamanistic, tradition after the language shift and atheistic propaganda in the North, among the Nenets. The material is based both on ethnographic fieldwork on the Island of Kolguyev, Barents Sea, and on archival work. The narrators of tradition tend to both minimize and maximize the gap between their telling and the Nenets tradition. The gaps are mainly created with the frames of the narratives. At the same time, the tellers implicitly define their relationship to shamanism. 